\title{
A NEW LEGAL SOLUTION ON RECIDIVISM IN SERBIAN CRIMINAL LEGISLATION
}

\author{
Đorđe Đorđević, Ivana Bodrožić ${ }^{1}$ \\ University of Criminal Investigation and Police Studies, Belgrade, Serbia
}

\begin{abstract}
From the adoption of the Criminal Code in 2006 until the latest amendments of 2019, the Serbian criminal legislation treated recidivism as an optional aggravating circumstance, which had its specific legal status in comparison with other mitigating and aggravating circumstances. According to the new legal solution, instead of being optional, recidivism has become a mandatory aggravating circumstance. Together with clearly specified conditions for harsher penalties this narrows down the possibility of free judicial decision-making when meting out punishment. The paper answers several questions: whether harsher penalties for recidivists are only the result of continuous tightening of repression at a normative level, whether and to what extent the criminal-law framework has been improved, and whether returning to some solutions, which were not normally applied in court practice, can be marked as approriate to achieve the desired degree of crime prevention. Final critical conculusion is that the new legal solution on recidivism appears regressive, given that the court is strictly bound by the law through oblitatory conditions regarding prior and persistent offending, which is in compliance with the general trend of tightening repression at the normative level and reducing the role of the court to the level of administrative application of the norm.
\end{abstract}

Keywords: recidivism, multiple recidivism, Criminal Code, sentencing, aggravating circumstances.

\section{INTRODUCTION}

The most recent changes in substantial criminal legislation of the Republic of Serbia, envisaged in the Act on Amendments and Additions to the Criminal Code which entered into force on $1 \mathrm{De}$ - cember 2019, have introduced substantial changes in the form and content, the essence and legal effect of the institute of recidivism, a significant general criminal-law institute in the sentencing pro-

1 Corresponding author: ivana.bodrozic@kpu.edu.rs 
cess. In the broadest sense, recidivism means that a previously convicted person has reoffended. However, from the adoption of the Criminal Code (CC) in 2006 until the latest amendments of 2019, the Serbian criminal legislation treated recidivism as an optional aggravating circumstance, which had its specific legal status in comparison with other mitigating and aggravating circumstances from Article 54 (1) of the CC. It is supported by the fact that it was regulated in a separate norm in Article 55 of the CC and that it was clearly indicated to the court which circumstances shall be taken into account when assessing whether recidivism will be recognized or used as an aggravating circumstance. According to the new legal solution, instead of being optional, recidivism has become a man- datory aggravating circumstance that together with clearly specified conditions for harsher penalties narrows down the possibility of free judicial decision-making when meting out punishment.

In this paper, an overview is provided of the development and legal effect of recidivism before and after the adoption of the CC. This is an attempt to answer several questions: whether harsher penalties for recidivists are only the result of continuous tightening of repression at a normative level, whether and to what extent the criminal-law framework has been improved, and whether returning to some solutions, which were not normally applied in court practice, can be marked as appropriate to achieve the desired degree of crime prevention.

\section{TYPES OF RECIDIVISM AND CHRONOLOGICAL REVIEW OF LEGAL SOLUTIONS 1947-2019}

Although the conceptual framework of recidivism depends on the scientific discipline within which it is given, in this paper it is dealt solely with criminal-law concept of recidivism and its classifications, offering the analysis of the character and legal effect of recidivism in various stages of its legal regulation in national legislation. The aim is to determine the level of conditionality and influence that the previous legal solutions had on the new solution, which were introduced in the latest changes of the CC text.

In criminal-law sense, recidivism exists when the previously convicted offender reoffends (Stojanović, 2015: 314). Depending on the chosen criterion, recidivism can be classified as follows: a) general or special, depending on whether the new crime and the one for which the offender was previously convicted are the same, similar or different in terms of category or gravity of offense (qualitative criterion); b) prior or persistent, depending on the number of offences for which the offender was previously convicted and the new offense (quantitative criterion); c) time-limited or time-unlimited, depending on the period of time which must elapse or does not have to elapse between the previous offense(s) for which the offender was convicted and the new one (time criterion); and d) actual or apparent, depending on whether the offender served the previous sentence in full, partially or has not served it at all, (penological criterion) (Konstantinović, 1977: 389). 
Historically, recidivism has been recognized as a basis for harsher punishment in Roman law, which included the rule consuetudo delinquendi est criumstantia aggravandi delictum et deliquentem acrius puniendi (Miladinović, 1982: 291), which means that "custom to offend is a circumstance which aggravates guilt and due to which the offender must be punished more strictly", as well as the rule multiplicata transgressione crescat poenae infictio, which means that "the penalty becomes stricter for the repeated criminal offense" (Bodrožić, 2019: 271).

The stated rules do not distinguish between recidivism as a rule when meting out punishment and real concurrency, but undoubtedly suggest that recidivism is recognized as a factor contributing to a higher quantity of crime and social danger. Here, we refer to the attitude that recidivism implies a high degree of culpability, which is reflected in the offender's persistence to commit a crime and reoffend even after the sentence for the previous offense has been served; thus, it can be taken as an aggravating circumstance that the previous conviction was without effect, i. e. that he did not take the previous conviction seriously, which speaks in favour of a higher degree of culpability and justification of the corresponding social-ethical reproach (Bačić, 1995: 381-382) recidivism implies stricter punishment, but it does not imply the attitude that nothing can be achieved by penalty, as an instrument of state response to crime, to prevent recidivism as a negative social phenomenon. The presence of such attitudes may be supported by the rule quod ab initio vitiosum est, non potest tractu temporis convalescere, which means "that which is bad from the beginning does not improve by length of time"; this rule nullifies both preventive and suppressive possibilities of pun- ishment and is not of significance for any form of social treatment, including criminal-law treatment.

There are different opinions on the question of mutual relationship between punishment of deprivation of liberty (imprisonment) and recidivism. On the one hand, there are affirmative opinions pertaining to the effects of imprisonment on consistency of high rates of recidivism, suggesting that penal policy needs tightening. On the other hand, there are opinions that the penalty of deprivation of liberty is inefficient and counter-productive and that it puts recidivist in a situation that crime becomes his destiny (Simeunović-Patić, 2016: 196).

Observed chronologically, recidivism as a general criminal-law institute first appeared in the General Criminal Code of the People's Federal Republic of Yugoslavia (1947), adopted on December 4, 1947. This Code accepted the objective concept of recidivism, for the existence of which it was necessary to fulfil several formal, cumulative conditions such as: that the person who was previously convicted repeated the offense, irrelevant of a certain form of guilt; that the new criminal offense is more serious in its nature; and that the new criminal offense was committed within five years from the day of the penalty being served or extinguished. According to Article 58 (6) of this Code, recidivism was determined as a mandatory aggravating circumstance which, according to the presented classifications, was general, prior, time-limited, and actual. The main characteristic was that recidivism was differentiated solely by objective criteria, which was the solution that fully neglected subjective factors related to the personality of a recidivist. 
The next legal act was the Criminal Code of 1951, which (with certain changes) accepted a similar concept of recidivism, starting from the general assumption that recidivism is mandatory aggravating circumstance. In Article 40 of this Code, recidivism was again dominantly determined by objective criteria; in addition, it was also required that both previous and newly committed criminal offenses were committed with premeditation. The conditions for the existence of recidivism were the following: that the offender was previously sentenced to imprisonment for a premeditated crime; and that, within five years counting from the day of the sentence being partially or fully served, he committed a new premeditated crime for which the punishment of imprisonment is stipulated by law (Jocić, 2019: 231). Recidivism was general, prior, time-limited and actual, with the characteristic of a mandatory aggravating circumstance.

The Act on Amendments and Additions to the Criminal Code (1959) changed the provision on recidivism in Article 40, stipulating that in deciding upon the punishment the court shall take into special consideration whether the offender was previously convicted, whether the most recent offence is of the same type as a previous one, whether both acts were committed with the same motive, and whether and how much time elapsed since the punishment had been served or pardoned. In this Act, the concept of recidivism was set considerably more widely, as only two conditions were required for its existence: the offender's previous conviction for the criminal offense, and criminal reoffending after the conviction. Recidivism was no longer a mandatory aggravating circumstance and it became an optional aggravating circumstance. The law obli- gated the court, when meting out penalty for repeated criminal offences, to take into consideration particularly whether the offense was of the same kind. This clearly points to the introduction of the so-called special recidivism, or singling out of its significance.

Therefore, recidivism was general and special, and it included prior offending, but also persistent offending; the provision of Article 40, which specified the notion of persistent offending and on the basis of which the court was specially authorized to evaluate the offender's propensity to commit a crime and possibly impose a stricter penalty. In case of prior offending, recidivism was time-unlimited but, in case of persistent offending, it was time-limited. The classification into actual or apparent recidivism is not observable in the legal text, but it can be concluded through interpretation that there is apparent recidivism, which would exist even in cases when the penalty was imposed but not executed due to the statute of limitation (for instance), or when there was remittal from punishment.

According to Article 40a of this Code, the conditions for the existence of persistent offending were as follows: that the offender had at least twice been convicted for criminal offenses with a term of imprisonment of at least three months; that the new criminal offense was committed with premeditation and that the penalty stipulated for it is imprisonment; that the offender manifests propensity to offend further, provided that no more than five years have elapsed from the day of release of the offender from the previous penalty being served until he reoffended. Restrictions related to imposing a harsher penalty meant that it must not exceed a double term of prescribed 
imprisonment, or rigorous prison sentence or the maximum penalty imposed (Đokić, 2019: 316).

The Criminal Code of the Socialist Federal Republic of Yugoslavia (1977) largely kept the solution from the previous changes of the Criminal Code. Thus, the 1977 Code still differentiated between prior offending and persistent offending. Article 41 of the CC specified that the requirement for prior offending was only that the offender had been previously convicted. Under Article 46 of the CC, the requirement for persistent offending was only the changed condition, which required that the previous conviction included imprisonment for a term of at least one year. The prior offending preserved the character of an optional aggravating circumstance, and persistent offending was the ground for imposing a harsher penalty.

The institute of persistent offending was revoked by the 2003 Act on Amendments and Additions to the Criminal Code, when the Criminal Code of the Federal Republic of Yugoslavia (1993) was replaced by the Basic Criminal Code (2003). The condition that the offender had previously been sentenced twice for premeditated criminal offence to imprisonment of at least a year was changed and the possibility of stricter penalty was prescribed in case the offender was convicted only once for a criminal offense. "This was an unusual solution, which kept the possibility of imposing a harsher punishment for repeated offending at the moment when some other examples of legislation completely desist from harsher punishment of multiple offending" (Kolarić, 2020: 212). This is the reason why recidivism could no longer be considered and called persistent offending from the aspect of quantitative criteria. The Basic Criminal Code (2003) kept the provision on prior offending (Article 40 (2)), whereby persistent offending was equalled with prior (one-off) offending; it is a partially paradoxical situation regarding the quantitative criterion for the classification of recidivism. Certainly, recidivism had the character of an optional ground for tightening penalty but, regarding its legal nature, it may be said that recidivism was general, prior (one-off), time-limited and actual. The Basic Criminal Code started from the attitude that, in terms of criminal policy, it was disputable to punish for multiple offending the person who had previously been punished (i.e. convicted).

Considering the modalities of criminal-law response to recidivism, there are various solutions in comparative legislation. Namely, recidivism has implications on sentencing either in the form of an optional aggravating or exacerbating circumstance, which can be obligatory (which was the case in the Criminal Code of Italy in 1930) or optional (which was the case in the Basic Criminal Code of 2003). In some other pieces of legislation, recidivism implies a cumulative sentencing to a term of imprisonment and imposing a special security measure, which also consists of limited freedom of movement; an example of such a solution is provided in the 1908 legislation in England. Criminal-law response to reoffending in England was introduced by the Crime Prevention Act, which determined, first of all, the notion of a dangerous offender, which previously meant the offender who had been convicted to a term of imprisonment of at least three years, and who had been convicted previously at least three times and led dishonest and criminal life. This category of offenders could be imposed 
a punishment of ten-year preventive detention (Đokić, 2020: 282). The third solution regarding recidivism is to impose a security measure only, which can be done in two ways: the first one was envisaged in the Criminal Code of Switzerland in 1937, which specified that the court was free to choose between a penalty and a security measure; the second one was envisaged in the Criminal Code of Sweden in 1962, which specified that the court was obliged to impose just a security measure in case the legally stipulated conditions had been fulfilled (Delić, 2010: 241).

In 1986, the criminal legislation of Germany (Albrecht, 2001: 139-145) revoked the general legal sentencing minimum for a repeated criminal offence; in the amendments of the criminal legislation in 2003, recidivism as an aggravating circumstance was subsequently stipulated for criminal offenders against sexual freedom (Albrecht, 2011: 148162). However, the Alternative for Germany ( $A f d$ ) fraction proposed imposing harsher punishment for multiple recidivists (with a penalty of at least a half of prescribed penal range) and for certain criminal offenses where the offender manifested harmful inclinations and where such an offense can be assigned to his negative personal traits, and prescribing a sentencing minimum which will last for fixed five-year or ten-year periods (Stojanović, 2019a: 331).

"In recent legislation, there is an increasing abandonment of punishment for persistent offending, and even the court practice did not use the possibility of imposing harsher punishment in such cases. This is why the legislator decided to completely abandon it as grounds for harsher penalty" (Stojanović, 2016: 264).
CC (2006) recognizes only one type of recidivism: prior offending. Recidivism was envisaged in Article 55 of the CC, which prescribed as follows: in determining punishment for a perpetrator of a criminal offence which is committed after the perpetrator has served the sentence, or has been exonerated, or after the statute of limitations has expired, or after the punishment has been remitted upon the expiry of the period of revocation of a suspended sentence or admonition by the court, the court may consider it to be an aggravating circumstance; the court shall give particular consideration to the gravity of the previous offence, as well as whether the previous offence was an offence of the same kind as the new one, and whether both offences were committed with the same motives; the court shall also consider the circumstances under which the offences were committed and the time elapsed from the previous conviction, pronounced punishment, pardon, sentence which was subject to the statute of limitations, remittance of punishment or the expiry of the time limit for the revocation of the previous suspended sentence or pronounced admonition by the court (Article 55 of the CC). The classification into special and general reoffending is reflected in the part of Article 55 which instructs the court to take into special consideration whether the previous offence was of the same kind as the new one. This is not the condition for the existence of recidivism, but it is the circumstance that the court may use when deciding whether or not to consider recidivism as an aggravating circumstance. Bačić notes that criminological science considers that special recidivists are characterized by intensive criminal will and general recidivists by the extensive criminal will. The former have the 
propensity to commit the same criminal offenses; they are specialists who have high criminal technique and, from the aspect of legal order, this makes them more dangerous. General recidivists are delinquents who are ready to commit various criminal offenses, and for whom nothing is certain. Considering all this, it cannot be determined in advance which category of offenders, special or general recidivists, would be more dangerous (Delić, 2010: 238).

The nomotechnics which characterized the concept of reoffending in the CC is particularly marked by the fact that recidivism was regulated in a separate provision (Article 55 of the CC), and that it represented an optional aggravating circumstance, by which it was given a special quality compared with other listed circumstances which (depending on the modality of realization in case of specific wrong) can be regarded as both aggravating and mitigating.

According to the stated solution, it was the court that evaluated whether recidivism would be treated as an optional aggravating circumstance; therefore, the conditions were instructive and not mandatory (Bodrožić, 2019: 279).

The Act on Amendments and Additions to the Criminal Code (2009) did not change the rules on reoffending in Article 55 of the CC, but it did intervene within the provision on the margins of penalty mitigation. Thus, in case of special reoffending, Article 57 (3) of this
Act provides that the penalty cannot be mitigated for a criminal offender who had previously been convicted for the same criminal offense; but, according to Article 57 (4) of this Act, the court may mitigate penalty in case when it is authorized to exempt the offender from penalty, notwithstanding the limits set forth in Article 57 (1-3).

In the Act on Amendments and Additions to the Criminal Code (2012), the nomotechnical solution on special recidivism as the grounds for excluding penalty mitigation additionally contributed to the vagueness of the legal text on the effect of special recidivism in the area of prohibition of penalty mitigation, since the original norm excluded mitigation only in case of conviction for the same offense while the new one excluded it in case of the conviction for a similar criminal offense. In terms of the $\mathrm{CC}$, the notions of the same or similar offense are not synonymous; so, the notion of a similar criminal offense should have been added to the term of the same criminal offense, rather than make them interchangeable (Đorđević, 2010a: 170171; Stojanović, 2016: 270). This imbalance between the wording of the norm on special recidivism and its ratio legis (which is the expansion of the scope of prohibition) must have been resolved by applying the methods of formal logic in legal interpretation; otherwise, it resulted in situations which would be qualified as the classic contradictio in adjecto.

\section{A NEW LEGAL SOLUTION TO RECIDIVISM IN THE CRIMINAL CODE}

Before the adoption of the most recent Act on Amendments and Additions to the Criminal Code (2019), the Ministry of Interior (MoI) of the Republic of Serbia launched an Initiative for amending the Criminal Code, suggesting the intro- 
duction of the "three strikes" rule, aimed at ensuring stricter punishment for recidivists in certain categories of criminal offenses.

According to the proposal in the MoI Initiative, the criminal offender who repeats some of the enumerated criminal offenses will be given penalty that could not be less than one third of the maximum penalty prescribed for such offences, and not more than the maximum penalty prescribed for such criminal offenses: the exception refers to the most serious crimes, for the commission of which the recidivists will be given sentences that cannot be less than a half of the maximum penalty prescribed for these crimes and not more than the maximum penalty prescribed for these crimes, the so-called second strike. Should the recidivist repeat some of the crimes in the same group, he would be punished by a term of imprisonment which cannot be less than two thirds of the penalty prescribed for this crime, and not more than the maximum penalty prescribed for these crimes, the socalled third strike (Bodrožić, 2019: 274).

Therefore, this is the response to reoffending within the context of stricter punishment, which is selective in its nature. In other words, it is related to criminal offenses with the elements of violence and exhaustively listed categories of some other crimes whose implementation was related to the general part of the CC within the normative shaping of general rules on meting out the sentence that treated recidivism as a mandatory aggravating circumstance, which was not the case in the legal solution up to that moment considering that the law only listed the circumstances that the court would value when meting out penalty without their abstract clas- sification as aggravating or mitigating circumstances. A complex research on prediction of recidivism includes many parameters, ranging from basic demographic data (such as age, education, marital status, employment) to specific factors (referring to abuse of drugs and alcohol, length of sentences, number of previous convictions, type of offense, etc.). Accordingly, the research titled Expert research and analysis of recidivism in the Republic of Serbia, carried out by the Institute of Criminological and Sociological Research during 2017, suggests that there is no difference in recidivism whether we talk about the criminal offenses with or without the elements of violence. At the same time, it confirms that the greatest significance in predicting criminal recidivism can be attributed to the number of previous valid convictions, the number of disciplinary measures in the course of serving the sentence of imprisonment, and the total score gained at the risk assessment questionnaire (Stevanović, Međedović, Petrović, Vujičić, 2018: 14-15).

After considering the proposal on the "three strikes" institute, the working group of the Ministry of Justice decided to modify the suggested initiative and, as such, enter it into the Draft Act on Amendments and Additions to the CC. After the adoption by the Assembly, the existing provisions on recidivism from the former Article 55 of the CC were amended by introducing a new norm on multiple offending in Article 55a of the CC.

In accordance with the MoI Initiative, the provisions regulating the rules on meting out penalty in case of repeated offending were amended. In case of "prior offending", the previous conviction for a criminal offense committed with 
premeditation implies that the court is obliged to take it into account as an aggravating circumstance. According to the modified norm on reoffending (Article 55 of the CC), the court cannot pronounce a sentence below the limit prescribed by the law or a more lenient penalty if the criminal offender who committed the crime with premeditation had previously been convicted of a premeditated crime, and if five years have not elapsed since the previous conviction or sentence served.

According to the norm previously in force, the recidivism could (but did not have to) be taken as an aggravating circumstance, while in the new solution the legislator obliges the court to take the listed circumstances as aggravating under the prescribed conditions. The recidivism is general, prior, time-limited and actual.

Article 55 (2) includes the possibility of court leniency in terms of punishment, which is not in compliance with the provision in Article 57 (3), which also refers to court leniency of punishment; it envisages that the committed offence must be the same or similar, without mentioning the time elapsed from the previous conviction or sentence served, or required form of guilt.

In case of "multiple offending", the legislator made the circumstances of recidivism more substantial if additional conditions were fulfilled cumulatively. The conditions that make recidivism more serious are: two convictions to a term of imprisonment of at least one year for criminal offenses committed with premeditation and a time limit of up to five years between the date of releasing the offender from penalty served for one offence and the commission of another criminal offense. Such provisions give multiple offending the character of a mandatory aggravating circumstance. The recidivism is general, time-limited and actual.

Therefore, the effect of such multiple offending is that, in such a case, the penalty is mandatory to be meted out in the upper half of the range of the penalty prescribed for that crime. Thus, multiple offending appears as a mandatory aggravating circumstance with certain effect determined in advance, the penalty being within the upper half but not exceeding the particular maximum for that offense. Therefore, unlike the persistent offending from the Criminal Code of the SFRY (1977), the current provision on multiple offending does not have the effect of an exacerbating circumstance (Stojanović, 2019b: 282), but only leads to meting out harsher penalty within the penalty range prescribed for that offense (Kolarić, 2019: 27). Thus, its effect boils down to the obligation of the court to take into account as obligatory the significance imposed by the legislator. Of course, the court could do this (and it probably did very often) without this provision, but now it has become the court's obligation. In this way, the legislator actually narrows down the penal framework of a criminal offense, reducing it to its stricter half, prohibiting the court to mete out more lenient penalty, regardless of all other circumstances characterizing the given case (e.g. within the lower half of the prescribed penalty) even in cases when there are circumstances that might lead to the reduction of penalty. As the legislator considered that the penal policy should be tightened, by amending the provisions on prior and persistent offending as mandatory aggravating circumstances, the legislator reduced the area for free judicial assessment in the sentencing process. 
The relationship between newly introduced provisions on prior and persistent offending and the existing provisions on reducing penalty seems to be rather unharmonized and debatable in several ways. Without analysing numerous attitudes of theorists who dispute the justification of the solution to prohibit penalty mitigation, we shall review just the relationship between the newly introduced provisions and the provisions on penalty mitigation (Đorđević, 2010b: 171; Ristivojević, 2012: 46; Lazarević, 2013: 421).

In terms of prior offending, the CC stipulates that a consequence of such a circumstance is the prohibition to the court to mitigate the penalty (Article 55 (2) of the CC). Therefore, the condition is a conviction for any premeditated criminal offense, provided that not more than five years elapsed since the commission of such offence. However, Article 57 (3) provides for the prohibition to mitigate penalty (any kind of leniency, except when the conditions are fulfilled for exoneration from punishment) if the offender had already been convicted (at any time) for the same or similar crime, which is time-unlimited recidivism. Therefore, various conditions for reoffending (which is in one case general but time-limited and in another case special but time-unlimited) produce (rather inconsistently and illogically) various consequences: in one case, the court is precluded from mitigating penalty; in another case, it cannot exercise any leniency (except for exoneration from punishment). In such a state-of-affairs, various combinations of the required conditions can create complicated situations and result in illogical solutions.

In terms of persistent offending, the situation is even more complicated and illogical. Although, in principle, we can easily agree with the statement that the institute of multiple offending and mitigation of penalty seem incompatible (Stojanović, 2019b: 283), the provision of the CC on multiple offending leaves space for certain dilemma regarding the possibility to mitigate penalty in case the conditions for multiple offending have been fulfilled. The provision on multiple offending does not mention the possibility to mitigate penalty, but it does not exclude it either, which is the case in prior offending. Taking into account the already mentioned discrepancy between the provisions on recidivism and penalty mitigation, it is theoretically possible to imagine three possible options.

The first one is that the provisions on multiple offending do not interfere with the possibility to apply the institute of penalty mitigation (unless the conditions from Article 57 (2-3) of the CC have been fulfilled), since the CC does not mention anything about that in the provisions on multiple offending (unlike the provision on prior offending). However, fulfilling the conditions for multiple offending automatically implies fulfilling the conditions for prior offending (given that the former are stricter); thus, based on Article 55 (2) mitigation of penalty (by the court) is prohibited, unless it is provided for by the law or in cases where exoneration from punishment can be declared.

This leads to the second option: in case of multiple offending, only the judicial mitigation of penalty is prohibited, but not the legal mitigation of penalty, which corresponds to the provision on prior offending (unless the conditions of Article 57 (2-3) of the CC have been fulfilled). Thus, in case of legal mitigation of penalty which would be allowed according to this option, the question 
arises on the limits of mitigation because it is unclear what would be considered a special minimum: a special minimum of the part which is provided by law, or half the range of the prescribed punishment which practically becomes the new special minimum in case of multiple offending.

The third option seems most likely (although equally illogical). Taking into account the assumed intention of the legislator and the formulation that "the court shall prescribe penalty above a half of the range of the penalty stipulated", this option entails that, in case of fulfillment of conditions for multiple offending, there is an absolute prohibition of mitigation. Naturally, it does not include the possibility of mitigation in case the conditions have been fulfilled for remittance from penalty, which is prescribed in Article 55 (3) and in Article 57 (4) of the $\mathrm{CC}$, in which case there is no question of limitations of penalty mitigation. The application of new provisions on recidivism, especially of the third option involving complete prohibition of mitigation, can result in great unevenness when determining the penalty in not so different cases, which in their gravity do not require such drastic differences in penalty. Thus, for instance, a person who committed a criminal offense of aggravated larceny, who is not a recidivist, can be punished to a minimum one-year imprisonment; in case there are grounds to mitigate the imposed penalty, he may be sentenced to three-month imprisonment. In case the perpetrator of the same criminal offense had already been convicted for any premeditated criminal offence in the previous five years, his penalty cannot be mitigated because he is a recidivist (unless it is prescribed by the law or there are grounds for remitting the punishment), and he can be punished to one-year imprisonment at least. If the offender had already been convicted twice to a term of imprisonment of at least one year with time condition being fulfilled, he can be punished to at least four years and seven months of imprisonment. While the committed offense can be accompanied by many rather significant mitigating circumstances, they could not influence the punishment to be less than it is stipulated. This can result in unfair solutions, so we can hardly agree with the statement that this matter is of no great practical significance (Stojanović, 2019b: 283).

Although the conditions for the existence of multiple offending according to the current legal solution are very similar to those in the 1977 Criminal Code of the SFRY (Kolarić, 2020: 213), the effect of the current legal solution on multiple offending is substantially different from the one envisaged in the 1977 Criminal Code. In the 1977 Criminal Code provisions, the possibilities of the court were considerably larger if the conditions for multiple offending had been fulfilled; in determining the sentence, the court could use the expanded penal framework (higher special penal maximum). In the current legal solution, the situation is somewhat opposite; the penal framework has been reduced to a half, to be more precise to the upper half of the prescribed penalty range for that offense. It means that the possibilities of the court when determining the sentence are also reduced, i.e. the court is practically forced to work within the newly formed penal framework.

This raises the question of what has been gained by the new legal solution. Can the offender be punished more strictly due to the circumstance that the conditions 
for the multiple offending have been fulfilled? The answer is negative. The only consequence, which is by no means insignificant, is that the court cannot pronounce the sentence to such an offender in the lower half of the prescribed range. Therefore, while the old solution manifested stricter approach by raising the special maximum of the prescribed penalty and thus giving the court more possibilities in determining sentence, the present solution practically raises the special penalty minimum and narrows down the penal framework, thus reducing the possibilities of the court when determining the sentence.

For these reasons, it is very hard to agree with such (or any other) solution which is connected with the intentional reduction of the court's discretionary authority in free judicial assessment; such a solution leads into an undesired and retrograde direction which criminal-law theory rejected a long time ago. Hypothetically speaking, the endpoint on this path would be to reinstate the long-abandoned and forgotten system of fixed penalties for causally determined criminal offences (characteristic of some ancient historical periods and systems). Thus, by enacting such solutions, the legislative power shows certain distrust in court and tries to reduce the courts' influence in determining the sentence (Đorđević, 2018: 171).
On the one hand, the amendment to the provisions on recidivism and the introduction of a kind of "three strikes" institute are partially a reflection of the general political climate in the society which is striving to deal with re-offending at the level of stricter punitive response, by tightening the penal policy of courts. The "three strikes" institute is a powerful instrument of penal populism; from the adoption of the California initiative, it increased prison population to 100,000 , resulting in prison overloading and in 2011 decision of the Supreme Court (Brown v. Plata, the United States Supreme Court Decission) that the prison population should be reduced to 46,000 (Oleson, 2015: 281). In that context, Bodrožić points out to continuous tightening of punitive response and increase in the catalogue of incriminations, along with preventive modality of response to endangering and violation of legally protected values not characteristic for criminal law; notably, this is not a feature related to the national legislator, but to the negative criminal-policy trends at the level of relevant European documents as well (Bodrožić, 2017: 226-227). At the same time, the legislator seems to have forgotten that advocating too strict and too wide criminal-law repression often has harmful consequences both for an individual and for the society, and ultimately does not contribute much to crime prevention.

\section{CONCLUSION}

The phenomena of reoffending and persistent (multiple) offending have given rise to many debates in criminology and penology. Although there are various comparative-law solutions that determine the scope and legal effect of recid- ivism in criminal legislations, it seems that the development of criminal-law dogmatism (relying on court practice as a parameter for applying or non-applying the norms, as well as its adequacy in relation to the type of criminal behav- 
iour) undoubtedly led to the fact that the process of determining the sentence was accompanied only by instructive conditions, which left enough space for the court to value previous conviction within the context of all aggravating and mitigating circumstances. The new legal solution on recidivism appears regressive, given that the court is strictly bound by the law through obligatory conditions regarding repeated and multiple offending, which is in compliance with the general trend of tightening repression at the normative level and reducing the role of the court to the level of administrative application of the norm.

Therefore, we think that returning to the solutions that have not been applied in the court practice is contradictory; although the legislator was guided by certain criminal-policy criteria, the legislator should rely on court practice as the most reliable landmark in the application of a norm. In the end, there is an open question whether stricter punishment for recidivism would lead to achieving the special preventive effect of penalty, particularly when the goals of rehabilitation and resocialization of a convicted person actually mean only returning to previous, earlier, younger stage of criminal activity (Schmalleger, 2020: 273). It also remains disputable whether stricter punishment may achieve the desired degree of crime prevention from the general point of view.

\section{ACKNOWLEDGEMENTS}

The paper is the result of research on the project Development of institutional capacities, standards and procedures for the fight against organized crime and terrorism in the conditions of international integrations (No. 179045), which is financed by the Ministry of Education, Science and Technological Develop- ment, and carried out by the University of Criminal Investigation and Police Studies, Belgrade.

The paper was presented at the International Scientific Conference Responsibility in Legal and Social Context, held at the Faculty of Law, University of Niš, on 18 September 2020.

\section{REFERENCES}

Albrecht, J. H. (2011). Sexualstrafrecht - Reformen und Ergebnise. Recht der Jugend und des Bildungswesens, 59(2), 148-162.

Albrecht, J. H. (2001). Sentencing and punishment in Germany. In M. Tonry (Ed.), Penal reform in overcrowded times (pp. 139-145). Oxford: Oxford University Press.

Bačić, F. (1995). Krivično pravo: opći dio. Zagreb: Informator.

Bodrožić, I. (2017). Negativne kriminalno-političke tendencije i krivična dela terorizma u zakonodavstvu Nemačke. Srpska politička misao, 24(1), 213-227.

Bodrožić, I. (2019). Institut „tri udarca“ - opravdanost ili ne. In S. Bejatović (Ed.), Izmene ukrivičnom zakonodavstvu i statusu nosilaca pravosudnih funkcija $i$ adekvat- 
nost državne reakcije na kriminalitet (međunarodni pravni standardi i stanje u Srbiji) (pp. 271-284). Zlatibor: Intermex, Srpsko udruženje za krivinopravnu teoriju i praksu.

Delić, N. (2010). Zabrana (isključenje) ublažavanja kazne u određenim slučajevima. Crimen, 1(2), 228-245.

Đokić, I. (2019). Istorijski osvrt na institut povrata u srpskom (jugoslovenskom) krivičnom pravu. In Đ. Ignjatović (Ed.), Kaznena reakcija u Srbiji (pp. 308-326). Beograd: Pravni fakultet Univerziteta.

Đokić, I. (2020). Preventivno zatvaranje učinilaca opasnih po društvo: višestruki povrat i mere bezbednosti. In Đ. Ignjatović (Ed.), Kaznena reakcija u Srbiji (pp. 279299). Beograd: Pravni fakultet Univerziteta.

Đorđević, Đ. (2018). Kaznena politika sudova u Srbiji - izazovi i mehanizmi unapređenja. In S. Bejatović (Ed.), Organizacija pravosuđa i efikasnost sudske zaštite (evropski standardi i stanje u Srbiji) - krivičnopravni aspekt (pp. 163-174). Zlatibor: Intermex, Srpsko udruženje za krivičnopravnu teoriju i praksu.

Đorđević, Đ. (2010a). Aktuelni problemi odmeravanja kazne u našem krivičnom pravu. In Đ. Ignjatović (Ed.), Stanje kriminaliteta u Srbiji i pravna sredstva reagovanja (pp. 160-176). Beograd: Pravni fakultet Univerziteta.

Jocić, D. (2019). Povrat kao okolnost kod odmeravanja kazne. In S. Bejatović (Ed.), Izmene ukrivičnom zakonodavstvu i statusu nosilaca pravosudnih funkcija $i$ adekvatnost državne reakcije na kriminalitet (međunarodni pravni standardi i stanje u Srbiji) (pp. 230-241). Zlatibor: Intermex, Srpsko udruženje za krivičnopravnu teoriju i praksu.

Kolarić, D. (2020). Višestruki povrat u krivičnom pravu Srbije-Osvrt na Zakon o izmenama i dopunama Krivičnog zakonika iz 2019. godine. In Đ. Ignjatović (Ed.), Kaznena reakcija u Srbiji (pp. 208-217). Beograd: Pravni fakultet Univerziteta.

Kolarić, D. (2019). Orijentacija zakonodavca u poslednjem zakonu o izmenama i dopunama krivičnog zakonika. Arhiv za pravne i društvene nauke, 1(3-4), 13-43.

Konstantinović, S. (1977). Uzroci recidivizma i tretman povratnika. Zbornik radova Pravnog fakulteta u Nišu, 17, 389-410.

Lazarević, J. (2013). Zabrana ublažavanja kazne-da li ne. In S. Bejatović (Ed.), Nova rešenja u kaznenom zakonodavstvu Srbije i njihova praktična primena (pp. 421-424). Zlatibor: Intermex, Srpsko udruženje za krivičnopravnu teoriju i praksu.

Miladinović, V. (1982). Istorijski osvrt na institut povrata. Zbornik radova Pravnog fakulteta u Nišu, 22, 291-309.

Oleson, J. C. (2015). Habitual criminal legislation in New Zealand: Three years of three stikes. Australian and New Zealand Journal of Criminology, 48(2), 277-292.

Ristivojević, B. (2012). Aktuelna pitanja sadašnjeg stanja materijalnog krivičnog zakonodavstva Srbije. In S. Bejatović (Ed.), Aktuelna pitanja krivičnog zakonodavstva (normativni i praktični aspekt) (pp. 42-68). Zlatibor: Intermex, Srpsko udruženje za krivičnopravnu teoriju i praksu. 
Schmalleger, F. (2020). Criminal justice: A brief introduction (13th ed.). New York: Pearson.

Simeunović-Patić, B. (2016). Povrat: kriminološki aspekti. In Đ. Ignjatović (Ed.), Kaznena reakcija u Srbiji (pp. 195-213). Beograd: Pravni fakultet Univerziteta.

Stevanović, I., Međedović, J., Petrović, B., \& Vujičić, N. (2018). Ekspertsko istraživanje $i$ analiza povrata u Republici Srbiji. Beograd: Institut za kriminaloška i sociološka istraživanja.

Stojanović, Z. (2019a). Krivično pravo: opšti deo. Beograd: Pravni fakultet Univerziteta, Pravna knjiga.

Stojanović, Z. (2019b). Komentar Krivičnog zakonika. Beograd: Službeni glasnik.

Stojanović, Z. (2016). Komentar Krivičnog zakonika. Beograd: Službeni glasnik.

Stojanović, Z. (2015). Krivično pravo: opšti deo. Beograd: Pravni fakultet Univerziteta, Pravna knjiga. 